\title{
An analysis of 45 patients with pure nasal fractures
}

\author{
İzole nazal fraktürü olan 45 hastanın değerlendirilmesi
}

\author{
Yakup ÇİL, ${ }^{1}$ Erkan KAHRAMAN ${ }^{2}$
}

\section{BACKGROUND}

Nasal fracture is generally encountered alone or in combination with other serious injuries. The objective of this study was to analyze patients who had pure nasal fracture.

\section{METHODS}

Forty-five records from patients with pure nasal fracture treated in the hospital between 7 October 2005 and 14 December 2011 were included. The following nasal fracture criteria were evaluated: age at the time of nasal trauma, gender, accident type, use of alcohol, findings of the physical examination, treatment time after the nasal fracture, and year and seasonal distribution.

\section{RESULTS}

The age ranged from 6-32 years, with a mean age of 21 years. The most frequent reasons of the injury were violence $60 \%$ ( 27 cases) followed by falling 31\% (14 cases), accidents $4.5 \%$ ( 2 cases) and sport injuries $4.5 \%$ ( 2 cases). The most frequent findings were tenderness in $71.1 \%$ (32 cases), followed by swelling in $51.1 \%$ ( 23 cases), nasal deviation in $42.2 \%$ (19 cases), and epistaxis in $15.6 \%$ (7 cases). Nasal bone fracture was diagnosed exactly by standard X-ray films in 91.1\% (41 cases).

\section{CONCLUSION}

In this study; pure nasal bone fractures occurred primarily among men under 25 years of age, and fights were found to be the main etiologic factor.

Key Words: Analysis; etiology; fracture; injury; nose.

\begin{abstract}
$A M A C ̧$
Nazal kemik kırıkları izole olarak görülebileceği gibi diğer ciddi travmalar ile birlikte de görülür. Bu çalışmanın amacı izole nazal kemik kırığı olan hastaları analiz etmektir.
\end{abstract}

\section{GEREC VE YÖNTEM}

Bu çalışmada, izole nazal kemik kırığı nedeniyle 7 Ekim 2005 ile 14 Aralık 2011 arasında hastanede tedavi edilen 45 hastanın bilgileri incelendi. Hastalar çalı̧̧ma kapsamı içerisinde; nazal travmanın olduğu zamandaki yaş, maruz kalınan travmanın tipi, alkol kullanımı, fiziksel inceleme bulguları, nazal kırık sonrası hastaneye başvuru zamanı ve tedavi zamanı ile nazal kırığın oluş zamanının yıllık ve mevsimsel dağılımları incelendi.

\section{BULGULAR}

Hastaların yaşları 6 ile 32 arasında değişiyordu ve ortalama yaş 21 idi. En çok travma nedeni olarak kavga olaylarını $\% 60$ (27 olgu), yüksekten düşme 31 (14 olgu), kaza \%4,5 ( 2 olgu) ve sportif olaylar $\% 4,5$ (2 olgu) takip ediyordu. En sık bulgu olan hassasiyeti \%71 (32 olgu), şişme \%51,1 (23 olgu), burun eğriliği \%42,2 (19 olgu), burun kanamas1 \%15,6 (7 olgu) takip ediyordu. Nazal kemik kırıklarının kesin tanıs1 41 olguda $(\% 91,1)$ düz grafi ile konuldu.

\section{SONUÇ}

Çalışmada izole nazal kemik kırıkları öncelikli olarak 25 yaş altı genç erkeklerde görülmüş olup temel etyolojik faktör olarak kavga bulunmuştur.

Anahtar Sözcükler: Analiz; burun; etyoloji; kırık; yaralanma.
The etiology of the nasal fractures differs from one country to another due to social, cultural, and environmental factors. The main etiologies of nasal fractures worldwide are falls, violence, traffic accidents, and sport injuries. ${ }^{[1]}$ Interpretation of these surveys was dif- ficult because there was also variation in the classification of injuries. ${ }^{[2,3]}$ The continuous communication of data associated with nasal trauma epidemiology is extremely important in order to provide the necessary information for preventive action aimed at reducing the 
incidence of nasal injuries. The objective of this study was to verify the age, sex, and the most frequent causes of nasal fractures treated in the hospital.

\section{MATERIALS AND METHODS}

The records of patients with pure nasal fracture diagnosis during the period from 7 October 2005 through 14 December 2011 were retrospectively evaluated. The diagnosis was based on the nasal bone radiography. 76 patients who had presented with nasal trauma associated with other maxillofacial bone fracture that had been confirmed with radiography were excluded. Nasal cavities were examined using anterior rhinoscopy and the presence of epistaxis and localization of the hemorrhage were recorded. All patients were treated with closed reduction by specialist. Closed reduction was performed under local anesthesia. Nasal packing and nasal splint were also applied in all patients. The packing and the nasal splint were removed at the $3 \mathrm{rd}$ and 7th days, respectively. The following criteria were evaluated: age at the time of nasal trauma, gender, accident type (interpersonal violence, car accident, fall, bicycle, motorcycle, sport, or occupational accident), use of alcohol (found through information from the patient and/or physical exam), findings of the physical examination, and treatment time after the nasal fracture, and year and seasonal distribution of the nasal fractures.

\section{RESULTS}

A total of 45 patients, 39 men $(86.7 \%)$ and 6 women $(13.3 \%)$, were included in the study (Table 1). The age ranged from 6-32 years, with a mean of 21. Postoperative follow-up period was 6 months, ranging from 3-9 months. The most frequent reason for nasal fracture was violence in $60 \%$ ( 27 cases) followed by falling in $31 \%$ (14 cases), accident in 4.5\% (2 cases) and sport injuries in $4.5 \%$ ( 2 cases) (Fig. 1).

The most frequent findings were tenderness in $71.1 \%$ (32 cases) followed by swelling in 51.1\% (23 cases), nasal deviation in 42.2\% (19 cases), and epi-

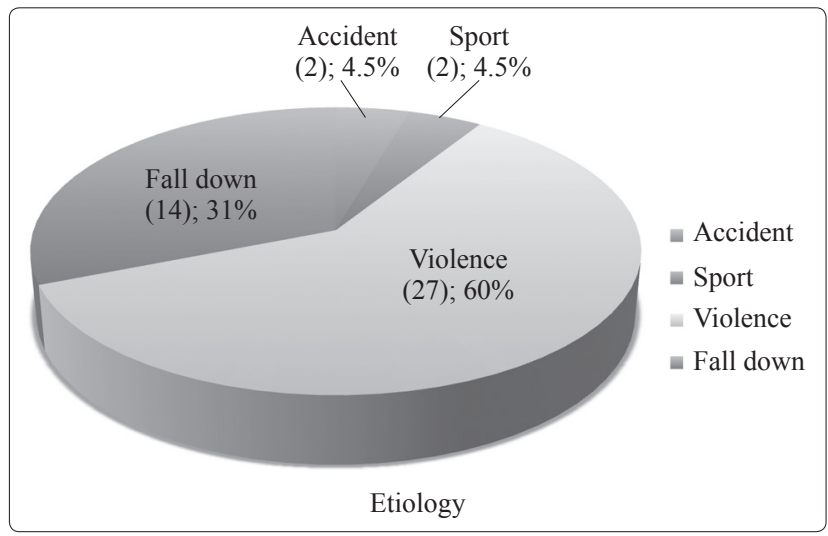

Fig. 1. Distribution of the nasal fractures according to related etiology.
Table 1. Demographic data of the patients

\begin{tabular}{|c|c|c|c|c|}
\hline No & Year / Age & Sex & Etiology & Season \\
\hline 1 & $2005 / 21$ & Male & Fall & Spring \\
\hline 2 & $2005 / 27$ & Male & Fall & Spring \\
\hline 3 & $2005 / 20$ & Male & Accident & Autumn \\
\hline 4 & $2006 / 21$ & Female & Fall & Spring \\
\hline 5 & $2006 / 22$ & Male & Violence & Summer \\
\hline 6 & $2006 / 20$ & Male & Violence & Spring \\
\hline 7 & $2006 / 21$ & Male & Violence & Autumn \\
\hline 8 & $2006 / 20$ & Male & Sport & Winter \\
\hline 9 & $2007 / 21$ & Female & Fall & Winter \\
\hline 10 & 2007 / 21 & Male & Violence & Spring \\
\hline 11 & $2007 / 7$ & Male & Fall & Spring \\
\hline 12 & $2007 / 23$ & Male & Violence & Summer \\
\hline 13 & 2007 / 21 & Male & Violence & Spring \\
\hline 14 & $2007 / 20$ & Male & Violence & Autumn \\
\hline 15 & $2007 / 20$ & Female & Violence & Autumn \\
\hline 16 & 2008 / 22 & Male & Violence & Winter \\
\hline 17 & $2008 / 21$ & Male & Violence & Autumn \\
\hline 18 & $2008 / 21$ & Male & Violence & Spring \\
\hline 19 & $2008 / 27$ & Female & Fall & Spring \\
\hline 20 & $2008 / 21$ & Male & Fall & Autumn \\
\hline 21 & 2008 / 32 & Male & Sport & Spring \\
\hline 22 & $2008 / 20$ & Male & Violence & Summer \\
\hline 23 & $2008 / 21$ & Male & Fall & Summer \\
\hline 24 & $2009 / 20$ & Male & Violence & Summer \\
\hline 25 & 2009 / 20 & Male & Fall & Spring \\
\hline 26 & 2009 / 20 & Male & Violence & Spring \\
\hline 27 & 2009 / 21 & Male & Violence & Autumn \\
\hline 28 & $2010 / 21$ & Male & Fall & Winter \\
\hline 29 & $2010 / 21$ & Male & Fall & Winter \\
\hline 30 & $2010 / 25$ & Male & Violence & Spring \\
\hline 31 & $2010 / 21$ & Male & Violence & Spring \\
\hline 32 & $2010 / 6$ & Female & Accident & Spring \\
\hline 33 & $2010 / 21$ & Male & Violence & Summer \\
\hline 34 & $2010 / 20$ & Male & Violence & Summer \\
\hline 35 & $2010 / 21$ & Male & Violence & Autumn \\
\hline 36 & $2010 / 20$ & Male & Violence & Autumn \\
\hline 37 & $2011 / 24$ & Male & Violence & Spring \\
\hline 38 & $2011 / 21$ & Male & Fall & Spring \\
\hline 39 & $2011 / 21$ & Male & Violence & Summer \\
\hline 40 & $2011 / 25$ & Male & Violence & Summer \\
\hline 41 & $2011 / 20$ & Female & Fall & Spring \\
\hline 42 & $2011 / 20$ & Male & Violence & Autumn \\
\hline 43 & $2011 / 21$ & Male & Violence & Autumn \\
\hline 44 & $2011 / 22$ & Male & Violence & Spring \\
\hline 45 & $2011 / 21$ & Male & Fall & Winter \\
\hline
\end{tabular}

staxis in $15.6 \%$ of cases ( 7 cases) (Fig. 2). Nasal-septal hemorrhages were drained in four patients $(8.8 \%)$.

Most of the cases were admitted to hospital on the same day of injury (average 0.8 days) and reduction of the nasal bone was typically carried out on the same day (Fig. 3). 
Diagnosis of nasal bone fracture was made positively by standard X-ray films in $91.1 \%$ of cases (41 cases). $8.9 \%$ of cases (4 cases) were suspicious for fracture and the exact diagnosis of the fracture was made by computerized tomography (Fig. 4).

Among three patients (6.7\%), physical examination showed that they had consumed alcohol.

Patient distribution in the years of 2005-2011 was not different according to year (Fig. 5). Seasonal evaluation indicated slightly higher incidence in the spring (Fig. 6).

\section{DISCUSSION}

The nose is located prominently in the face, and it is possible to analyze the pure nasal trauma etiology separately. Patients who had only pure nasal fractures without other maxillofacial bone fractures were analyzed in this study.

The most common cause of the nasal fracture in our series was physical aggression. Other studies indicated that vehicle accidents were the main cause of facial fracture. ${ }^{[4-6]}$ In this study we suggested the cause of pure nasal fractures was different from complex facial fractures as previous nasal fracture reports. ${ }^{[7,8]}$

A nasal injury might be associated with another

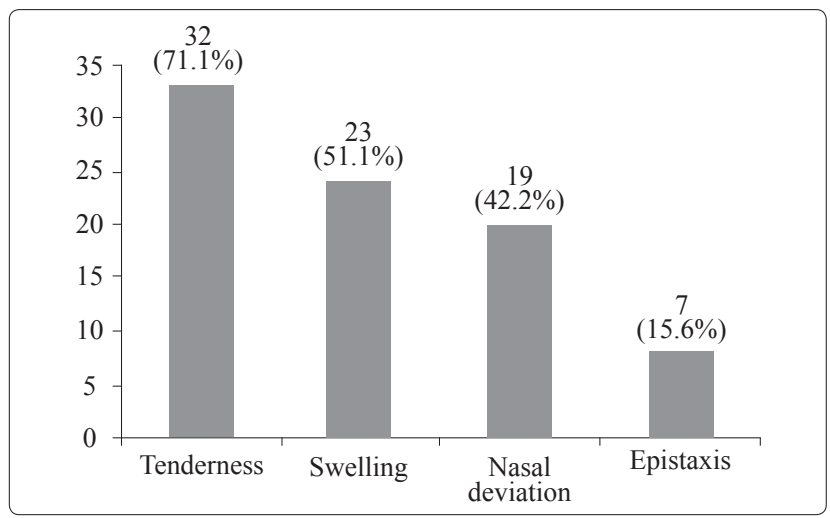

Fig. 2. Findings of the nasal fractures.

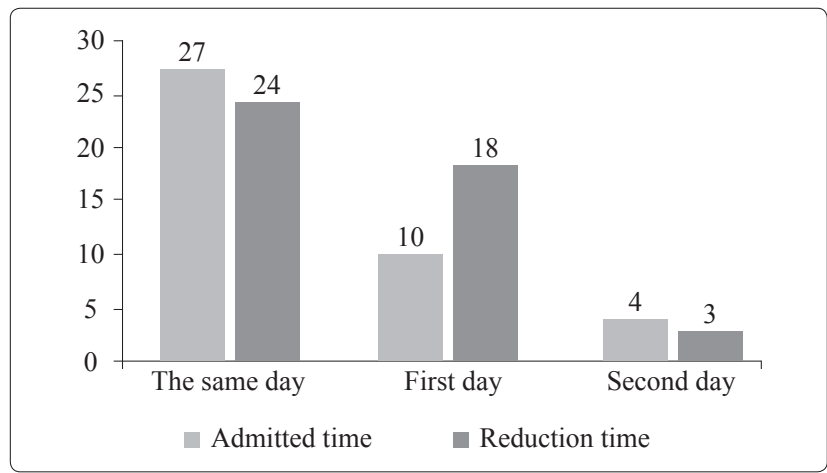

Fig. 3. Time interval between hospital consultations for the nasal fracture treatment time (day).

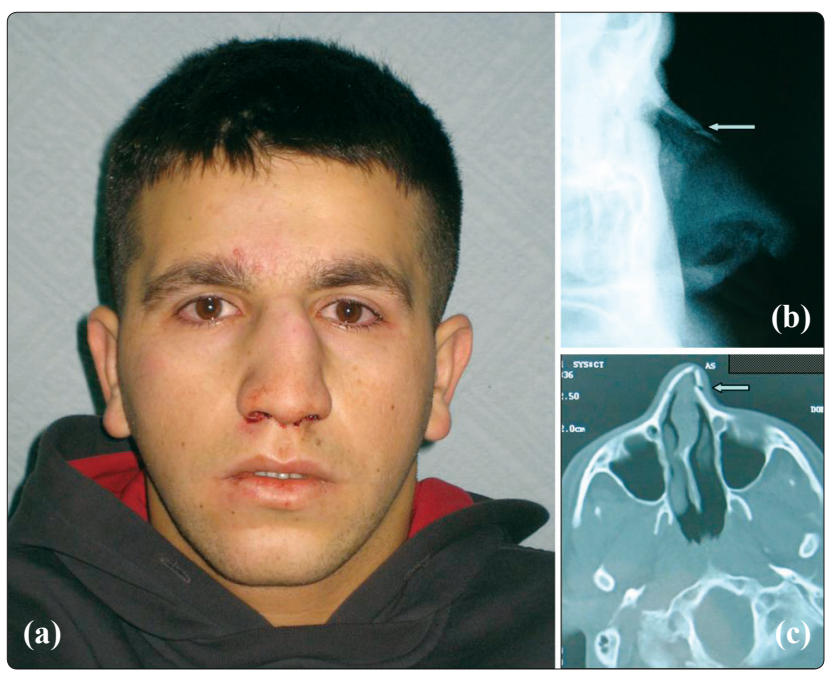

Fig. 4. (a) A 21-year-old patient with nasal fracture after falling down. (b) X-ray (arrow) and (c) further evaluation with computerized tomography was needed (arrow).

(Color figures can be viewed in the online issue, which is available at www.tjtes.org).

head and neck trauma. Physicians must consider the possibility of an associated facial fracture. ${ }^{[9]}$ If the patients have nasal trauma, all facial lacerations, swellings and deformities should be noted. The objective

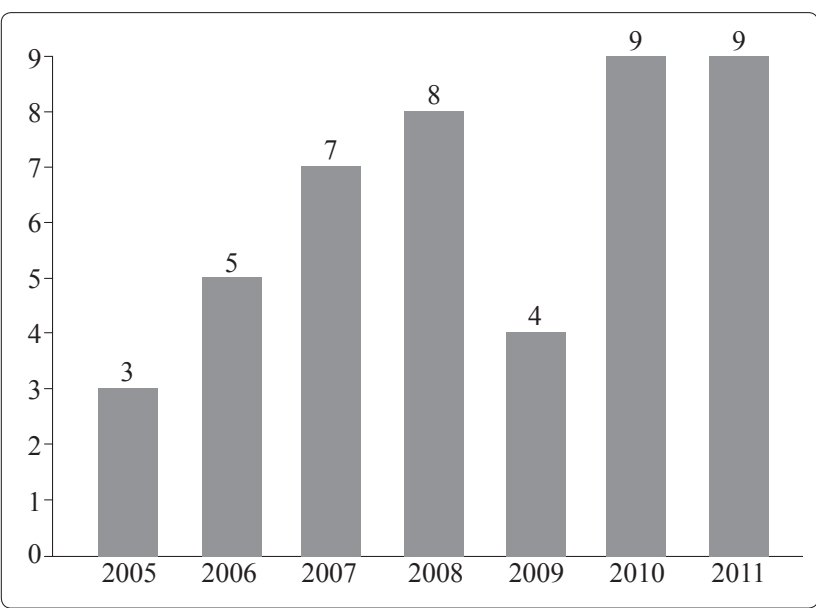

Fig. 5. Annual distributions of the nasal fractures.

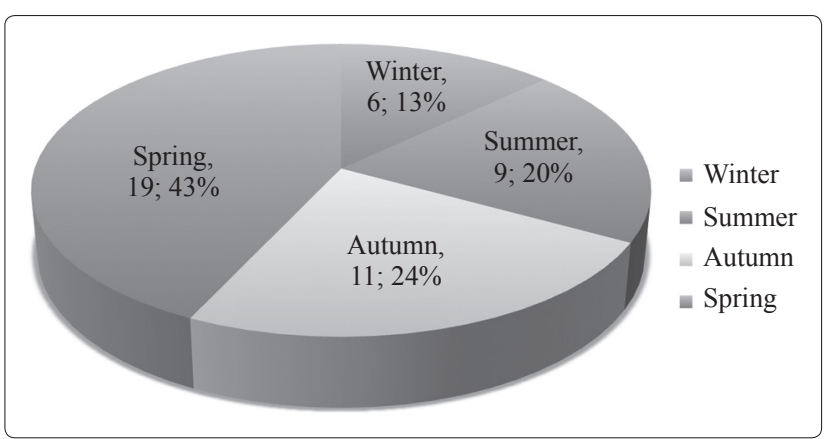

Fig. 6. Seasonal distributions of the nasal fractures. 
of this study was to analyze pure nasal fractures. Tenderness $(71.1 \%)$ was the most frequent finding in this study.

The association of alcohol consumption and facial fractures was well documented. Shapiro et al. ${ }^{[10]}$ describe a relationship in up to $45.0 \%$ of the cases. Interpersonal violence has become one of the major problems in many areas and the increase of these rates has been associated with alcohol consumption. A law increasing the age for permitting alcohol consumption that is rigorously upheld, and a larger social alert about the morbidity related to alcohol may reduce such traumas resulting from usage. Three patients' $(6.7 \%)$ examinations showed they had consumed alcohol.

Diagnosis of nasal fracture is based on the physical examination and radiographic evaluation. Simple radiographs of the nasal bone are important to show fractures and for medicolegal reasons. Computerized tomography is also useful for differential diagnosis of nasal bone fracture because the reliability of plain film is not $100 \%{ }^{[11,12]}$ Nasal fractures were diagnosed by nasal X-ray examination in $41(91.1 \%)$ of our patients, and further evaluation with computerized tomography was needed in four of the patients $(8.9 \%)$.

Incidence of trauma in pediatric and adolescent population was lower than the adult population. Many factors make this age group (0 to 18 years) different, such as: bone elasticity, relatively small facial size, and growth processes in young bone. ${ }^{[13]}$ There was only one pediatric patient in our series (Patient-32).

The peak age incidence of nasal fractures was difficult to compare, since the available studies have used different upper and lower age limits for their cases. In this study, the peak incidence was at age 21. Another study showed similar mean age. ${ }^{[14]}$ It was speculated that subjects in this age peak were becoming more involved in the same activities. We also observed physical aggression was encountered more between 20 and 30 years.

Annual distribution of nasal fracture was almost equal during the study period. Seasonal incidence was slightly higher in the spring. This finding may be explained with the increase of outdoor physical activity in the spring.

Male patients were mostly affected by facial injuries by a ratio of approximately $4: 1$; this ratio was within the range described in the literature, which varied between $6: 1$ and 11.8:1. ${ }^{[15-17]}$ Our series included six female (8.7:1.3) patients. This high vulnerability of men to most types of trauma may be associated with the fact that in our society men have more freedom in outdoor activities and are more involved in high-risk jobs, thus being more vulnerable to accidents.
Many studies reported on the etiology of facial fractures in various areas, ${ }^{[17-19]}$ but not many on pure nasal bone fractures. The primary objective of this study was to verify the age, sex, and the most frequent causes of the pure nasal fractures treated in the hospital.

Pure nasal bone fractures were encountered most frequently in young adult men due to interpersonal violence.

Conflict-of-interest issues regarding the authorship or article: None declared.

\section{REFERENCES}

1. Scariot R, de Oliveira IA, Passeri LA, Rebellato NL, Müller PR. Maxillofacial injuries in a group of Brazilian subjects under 18 years of age. J Appl Oral Sci 2009; 17:195-8.

2. Leong SC, Abdelkader M, White PS. Changes in nasal aesthetics following nasal bone manipulation. J Laryngol Otol 2008;122:38-41.

3. Rocchi G, Fadda MT, Marianetti TM, Reale G, Iannetti G. Craniofacial trauma in adolescents: incidence, etiology, and prevention. J Trauma 2007;62:404-9.

4. Scherer M, Sullivan WG, Smith DJ Jr, Phillips LG, Robson MC. An analysis of 1,423 facial fractures in 788 patients at an urban trauma center. J Trauma 1989;29:388-90.

5. Haug RH, Prather J, Indresano AT. An epidemiologic survey of facial fractures and concomitant injuries. J Oral Maxillofac Surg 1990;48:926-32.

6. Sargent LA, Fernandez JG. Incidence and management of zygomatic fractures at a level I trauma center. Ann Plast Surg 2012;68:472-6.

7. Kucik CJ, Clenney T, Phelan J. Management of acute nasal fractures. Am Fam Physician 2004;70:1315-20.

8. Fornazieri MA, Yamaguti HY, Moreira JH, Navarro PL, Hesbiki RE, Takemoto LE. Fracture of nasal bones: An epidemiologic analysis. Intl Arch Otorhinolaryngol Sao Paulo 2008; 12:498-501.

9. Ellis E 3rd, Scott K. Assessment of patients with facial fractures. Emerg Med Clin North Am 2000;18:411-48, vi.

10. Shapiro AJ, Johnson RM, Miller SF, McCarthy MC. Facial fractures in a level I trauma centre: the importance of protective devices and alcohol abuse. Injury 2001;32:353-6.

11. Oluwasanmi AF, Pinto AL. Management of nasal trauma-widespread misuse of radiographs. Clin Perform Qual Health Care 2000;8:83-5.

12. Smith H, Peek-Asa C, Nesheim D, Nish A, Normandin P, Sahr S. Etiology, diagnosis, and characteristics of facial fracture at a midwestern level I trauma center. J Trauma Nurs 2012;19:57-65.

13. Oji C. Fractures of the facial skeleton in children: a survey of patients under the age of 11 years. J Craniomaxillofac Surg 1998;26:322-5.

14. Hwang K, You SH, Kim SG, Lee SI. Analysis of nasal bone fractures; a six-year study of 503 patients. J Craniofac Surg 2006;17:261-4.

15.Hächl O, Tuli T, Schwabegger A, Gassner R. Maxillofacial trauma due to work-related accidents. Int J Oral Maxillofac Surg 2002;31:90-3.

16. Pombo M, Luaces-Rey R, Pértega S, Arenaz J, Crespo JL, García-Rozado A, et al. Review of 793 facial fractures treated from 2001 to 2008 in a coruña university hospital: types and 
etiology. Craniomaxillofac Trauma Reconstr 2010;3:49-54.

17. Naveen Shankar A, Naveen Shankar V, Hegde N, Sharma, Prasad R. The pattern of the maxillofacial fractures - A multicentre retrospective study. J Craniomaxillofac Surg 2012;40:675-9.

18. Klenk G, Kovacs A. Etiology and patterns of facial fractures in the United Arab Emirates. J Craniofac Surg 2003;14:7884.

19. Smith H, Peek-Asa C, Nesheim D, Nish A, Normandin P, Sahr S. Etiology, diagnosis, and characteristics of facial fracture at a midwestern level I trauma center. J Trauma Nurs 2012;19:57-65 